\title{
Fungus gnats (Diptera: Bolitophilidae, Diadocidiidae, Keroplatidae and Mycetophilidae) new to Finland
}

\author{
Alexei Polevoi, Jevgeni Jakovlev* \& Alexander Zaitzev
}

Polevoi, A., Jakovlev, J. \& Zaitzev, A. 2006: Fungus gnats (Diptera: Bolitophilidae, Diadocidiidae, Keroplatidae and Mycetophilidae) new to Finland. Entomol. Fennica 17: 161-169.

Thirty-seven species of fungus gnats new to Finland are reported. Eleven of these are reported in Fennoscandia for the first time: Diadocidia fissa Zaitzev, Macrocera estonica Landrock, M. nigricoxa Winnertz, M. pusilla Meigen, Boletina pallidula Edwards, Mycetophila morata Zaitzev, M. ostentanea Zaitzev, Trichonta nigritula Edwards, T. subterminalis Zaitzev \& Menzel, Neoempheria winnertzi Edwards and Neuratelia sintenisi Lackschewitz. The records are based on original material collected in large-scale trapping projects in Southern and Eastern Finland mainly in old-growth forests during 1997-1998. Detailed information on Finnish findings, and data on the general distribution of the species are given. Several species are known with only one (type material) or a few previous records ranging from Norway to Sakhalin. For two poorly-known species, Neuratelia sintenisi Lackschewitz and Rymosia pinnata Ostroverkhova, new figures of male genitalia are presented.

A. Polevoi, Forest Research Institute, RU-185910, Pushkinskaya 11, Petrozavodsk, Russia; E-mail: alexei.polevoi@krc.karelia.ru

J. Jakovlev, Finnish Forest Research Institute (METLA), Vantaa Research Unit, P. O. Box 18, FI-01301 Vantaa, Finland; *correspondent author's e-mail: jevgeni.jakovlev@metla.fi

A. Zaitzev, Moscow City Pedagogical Institute, Department of Biology, Faculty of Chemistry and Biology, 111568, Chechulina 1, Moscow, Russia; E-mail: zaitzev@cbf.mgpu.ru

Received 22 June 2005, accepted 11 November 2005

\section{Introduction}

Fungus gnats is a highly diverse group of nematocerous Diptera incorporating ca. 1500 species in the Palaearctic fauna and comprising about one tenth of all the Dipteran species recorded in Finland. The group has traditionally been considered to include five families in Europe - Bolitophilidae, Diadocidiidae, Ditomyiidae, Keroplatidae and Mycetophilidae - which were earlier treated as subfamilies in the family Mycetophilidae (Edwards 1925). At present all these families are included into the superfamily Sciaroidea (Väisänen 1984, Matile 1990, Hippa \& Vilkamaa 2005).

In Finland, the fungus gnat fauna has been fairly well studied. The first data on Finnish mycetophilids were published by Carl Lundström(Lundström 1906, 1909, 1912, 1913, 1914) and Richard Frey, whose data were included in 
the first Finnish Diptera checklist (Frey \& Stora 1941) and in Krogerus (1960). During 1960's, Risto Tuomikoski and Walter Hackman collected extensive material of mycetophilids throughout the country, mainly for taxonomical studies (Tuomikoski 1966, Hackman 1970, 1971, Gagné 1981). That material was utilized in a check-list of Finnish Diptera (Hackman 1980) comprising 485 species of fungus gnats. Since then, additions and deletions to the Finnish fauna of fungus gnats have been summarized by Silfverberg (1981, 1986, 1991, 1996, 2001) and Polevoi \& Jakovlev (2004). The latter review brought the total number of fungus gnat species in the Finnish fauna to 589.

However, the list by Polevoi \& Jakovlev (2004) is still far from complete. In Russian Karelia with rather similar nature, 616 species have been recorded after intensive studies during a period of just about twenty years during 19772000 using rearing of fungus gnats from macrofungi and collecting with netting and different kinds of traps (Jakovlev 1995, Polevoi 2000). We believe that at least a hundred additional species should be found in Finland. Moreover, the number of yet unknown species may be even much higher, as recent taxonomical works (e.g. Zaitzev \& Økland 1994, Polevoi 1995, 2001, Zaitzev 2003, Polevoi \& Hedmark 2004) have revealed many species new to science in Fennoscandia.

This paper is based on original material collected during 1997-1998 in different parts of Southern and Eastern Finland and introduces 37 species new to Finland. Sixteen of these species were already mentioned as known from Finland in the online database "Fauna Europaea" (Chandler 2005). However, these records are based on unpublished information and do not contain detailed data e.g. on collecting localities and dates.

\section{Study areas, material and methods}

The material was collected with trapping in oldgrowth forests in three different regions in Southern and Eastern Finland. The study areas were located in the biogeographical provinces of EteläHäme (Tavastia australis, Ta), Satakunta (St), Pohjois-Karjala (Karelia borealis, Kb) and Kai- nuu (Ostrobotnia kajanensis, Ok). A total of 51 sites of old-growth forest stands were studied. The pooled material consists of over 270,000 individuals and more than 500 species of fungus gnats. The material is deposited at the Zoological Museum of the Finnish Museum of Natural History, Helsinki. The sites where species new to Finland were found are listed in Table 1.

In $\mathrm{Ta}$ and $\mathrm{St}$, the material was collected by M. Kuussaari during 1998 in 19 old-growth forest stands. In each stand the trapping was done using five standard flight-window traps, one light trap and two bait traps baited with fermented sugar solution. The traps were operating from 4 May to 15 October and were emptied 8-9 times during the season. The pooled sample was 31,745 individuals.

In $K b$, the material was collected by M. Tietäväinen in the North Karelian biosphere reserve in the municipality of Ilomantsi using one Malaise trap in each of the nine sample plots placed in oldgrowth forest stands. The traps were operating from 14 July to 29 September and were emptied 9 times in 1997, and from 11 June to 2 October and emptied 17 times in 1998. The pooled sample was 67,103 individuals.

In $O k$, the material was collected by M. Kuussaari during 1997 in 23 old-growth forest patches in the municipalities of Kuhmo and Sotkamo. The trapping design was the same as in Ta and St. The traps were operating from 3 June to 8 October and were emptied 6-7 times during the season. The pooled sample was 177,739 individuals.

\section{The list of species new to Finland}

Higher taxonomy follows Fauna Europaea (De Jong 2005). The species recorded by us as new to Fennoscandia are marked by asterisk $(*)$.

\subsection{Heterotricha group}

Sciarosoma borealis Chandler, 2002. Sciarosoma Chandler is a genus with a problematic systematic position described on the basis of a single species from Norway and Russian Karelia (Chandler 2002) and later reported from Germany (Kallweit \& Jaschhof 2004) and from Czech Re- 
Table 1. The study sites, with information on their locality. Province = biogeographic province; Municip. $=$ municipality; Coords. $=$ coordinates $(E 27$ grid $)$, Year $=$ sampling year.

\begin{tabular}{|c|c|c|c|c|}
\hline Study site & Province & Municip. & Coords. & Year \\
\hline Ahvenus & St & Parkano & 6888: 3295 & 1998 \\
\hline Elimyssalo & Ok & Kuhmo & 7129: 3667 & 1997 \\
\hline Honkavaara & Ok & Kuhmo & 7091: 3632 & 1997 \\
\hline Iso-Saarijärvi & $\mathrm{Ta}$ & Ruovesi & 6882: 3337 & 1998 \\
\hline Jauhovaara & Ok & Kuhmo & 7106: 3603 & 1997 \\
\hline Jonkeri & Ok & Kuhmo & 7093: 3636 & 1997 \\
\hline Kolmikoura & $\mathrm{Ta}$ & Ruovesi & 6868: 3364 & 1998 \\
\hline Kotavaara & $K b$ & Ilomantsi & 6998: 3721 & 1997-1998 \\
\hline Kotiset & Ta & Lammi & 6794: 3396 & 1998 \\
\hline Kuivikkovaara & Ok & Kuhmo & 7125: 3654 & 1997 \\
\hline Kujanki & Ok & Kuhmo & 7086: 3618 & 1997 \\
\hline Lakeisnevankangas & $\mathrm{Ta}$ & Virrat & 6920: 3344 & 1998 \\
\hline Lauvuskylä & Ok & Kuhmo & 7089: 3626 & 1997 \\
\hline Luhtavaara & Ok & Kuhmo & 7152: 3610 & 1997 \\
\hline Lymylampi & St & Ikaalinen & 6862: 3319 & 1998 \\
\hline Metsäopisto & $\mathrm{Ta}$ & Kuru & 6866: 3320 & 1998 \\
\hline Multinharju & St & Ikaalinen & 6872: 3311 & 1998 \\
\hline Musturi & $\mathrm{Ta}$ & Ruovesi & 6865: 3362 & 1998 \\
\hline Nälkähittenkangas & St & Parkano & 6892: 3295 & 1998 \\
\hline Näveri & Ok & Kuhmo & 7104: 3599 & 1997 \\
\hline Pellinkangas & Ok & Kuhmo & 7135: 3594 & 1997 \\
\hline Petäjäjärvi & Ta & Kuru & 6871: 3320 & 1998 \\
\hline Pirhu & $K b$ & Ilomantsi & 6993: 3723 & 1997-1998 \\
\hline Pitkävaara & Ok & Kuhmo & 7162: 3617 & 1997 \\
\hline Puntari & Ok & Kuhmo & 7090: 3616 & 1997 \\
\hline Puukkohonka & $\mathrm{Ta}$ & Lammi & 6792: 3395 & 1998 \\
\hline Rengassalo & St & Parkano & 6897: 3285 & 1998 \\
\hline Riihisuo & Ok & Kuhmo & 7102: 3610 & 1997 \\
\hline Sudenpesänkangas & Ta & Lammi & 6789: 3403 & 1998 \\
\hline Susimäki & $\mathrm{Ta}$ & Ruovesi & 6864: 3355 & 1998 \\
\hline Särkijärvi & Ok & Kuhmo & 7111:3622 & 1997 \\
\hline Teerisuo & Ok & Kuhmo & 7091: 3608 & 1997 \\
\hline Tulisuo-Varpusuo & Ok & Kuhmo & 7164: 3616 & 1997 \\
\hline Urpovaara & Ok & Sotkamo & 7089: 3602 & 1997 \\
\hline Vepsä & Ok & Kuhmo & 7091: 3615 & 1997 \\
\hline Vesijako & $\mathrm{Ta}$ & Padasjoki & 6806: 3399 & 1998 \\
\hline
\end{tabular}

public and Finland with no locality data (Chandler 2005). It was not included in any existing family until the new concept of Sciaridae (Hippa \& Vilkamaa 2005) with Sciarosoma placed in the family Sciaridae, subfamily Sciarosominae. Material: 3 ऽึ, $K b$ : Kotavaara, 22.-29.VI.1998; 1 స, Ok: Luhtavaara, 15.-27.VII.1997.

\subsection{Family Bolitophilidae}

Bolitophila caspersi Plassmann, 1986. Previously known only from Swedish type material and specimens from Russian Far East (Zaitzev 1994). Reported from Finland with no locality data (Chandler 2005). Material: 1 o, Ok: Jonkeri, 27.VIII.-10.IX.1997; 1 त, $K b$ : Kotavaara, 15.29.IX.1997.

\subsection{Family Diadocidiidae}

* Diadocidia fissa Zaitzev,1994. Type specimens from Vologda province (Zaitzev 1994) were the only known specimens until now. Material: 2 ô, Kb: Kotavaara, 8.-15.IX.1997. 


\subsection{Family Keroplatidae}

\subsubsection{Subfamily Keroplatinae}

Tribe Keroplatini

Keroplatus tuvensis Zaitzev, 1991. A rare species of the testaceus group. Described from Tuva Republic (Zaitzev 1991) and later reported from Russian Karelia (Polevoi 1995) and from Czech Republic and Finland but with no locality data (Chandler 2005). Material: 1 $\hat{\sigma}$, Ok: Pitkävaara, 12.-25.VIII.1997.

Tribe Orfeliini

Pyratula perpusilla (Edwards, 1913). A European species; in Fennoscandia, previously recorded from Sweden (Plassmann 1974, 1978) and Norway (Økland \& Zaitzev 1997). Material:

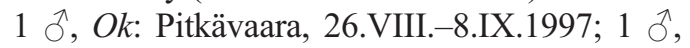
Ok: Tulisuo-Varpusuo, 8.-24.VIII.1997.

\subsubsection{Subfamily Macrocerinae}

* Macrocera estonica Landrock, 1924. This species is apparently widely distributed in the Palaearctic region but it was not earlier reported from Fennoscandia. The record from Finland (Chandler 2005) is given with no locality data. Material: 5 $\widehat{\jmath}, K b$ : Kotavaara, 14.-25.VIII. 1997.

* Macrocera nigricoxa Winnertz, 1863 (= M. tusca Loew). This species is widely distributed in Western and Central Europe. It has also been found in Israel (Chandler 1994a) and in Central Asia (Zaitzev 1994). The Finnish record is the first one from Fennoscandia. Material: $3 \hat{\partial} \widehat{\partial}, K b$ : Kotavaara, 15.-29.IX.1997; 3 §ิત, same site, 25.VIII.-8.IX.1998.

* Macrocera pusilla Meigen, 1830 (= M. nana Macquart). This species is widespread in Europe, including North Africa and Middle East (Chandler 1994a) and has also been reported from Central Asia and Japan (Zaitzev 1994). It was not, however, earlier found in Fennoscandia. Material: $9 \lesssim \precsim, K b$ : Kotavaara, 17.VII.-20.VIII. 1998.

\subsection{Family Mycetophilidae}

\subsubsection{Subfamily Gnoristinae}

Boletina digitata Lundström, 1914. Distributed in Europe and Middle East. In Fennoscandia, previously known from the type locality, viz. Kandalaksha, Murmansk province, Russia (Lundström 1914) and Sweden (Plassmann 1979). According to Plassmann (1979) and Catalogue of Palaearctic Diptera (Laštovka \& Matile 1988) this species has also been found in Finland, but was not mentioned in the Finnish Diptera check-list (Hackman 1980) nor in the updates published afterward. Chandler (2005) gives the Finnish record with no locality data. Material: 5 §ð, $K b$ : Kotavaara, 22.VI.-8.IX.1998. We have also found two males of this species in the collection of the Finnish Museum of Natural History, Helsinki: one male from $O b$ : Uleåborg (V. Wuorentaus) and another from Le: Malla (R. Frey).

Boletina jamalensis Zaitzev, 1994. Described from Siberia (Zaitzev 1994) and later found in Northern Europe (Økland 1996, Hedmark 1998, Polevoi 2000). The Finnish record was earlier published with no locality data (Chandler 2005). Material: 1 o, $K b$ : Kotavaara, 15.-29.IX.1997; 1 ô, same place, 2.-8.IX.1998; 1 ô, Ok: Luhtavaara, 17.-30.VI.1997; 2 ふ઼े, St: Lymylampi, 26.V.-12.VI.1998. We have also found two males of this species in the collection of the Finnish Museum of Natural History, Helsinki, both from Ka: Vehkalahti, 5.VI.1971 and 9.X.1971.

* Boletina pallidula Edwards, 1925. A rare European species not previously reported from Fennoscandia. The record from Finland (Chandler 2005) is given with no locality data. Material: 35 ठぇં, Kb: Kotavaara, 17.VII.-21.IX.1998; 1 ๙, Ta: Kotiset, 4.-17.VIII.1998; 1 §, Ok: Kujanki, 31.VII.-13.VIII.1997.

Boletina tiroliensis Plassmann, 1980. Species described from Austria (Plassmann 1980a), later found in Sweden (Hedmark 1998) and in several northern localities in Russia (Zaitzev 1994). The record from Finland (Chandler 2005) is given with no locality data. Material: 1 त, $O k$ : Kuivikkovaara, 15.-29.IX.1997; 1 ภ, Ok: Pellinkangas, 10.-28.IX.1997; 2 ふึô, Ok: 
Riihisuo, 12.IX.-7.X.1997; 1 $\hat{\sigma}$, Ok: Urpovaara, 12.IX.-8.X.1997.

Ectrepesthoneura tori Zaitzev \& Økland, 1994. A rare species described from Norway. Also known from Germany (Kallweit \& Plassmann 1999), Sweden (Kurina et al. 2005), Great Britain and Czech Republic (Chandler 2005). Material: 1 đ̃, Kb: Kotavaara, 11.-15.VI. 1998.

Tetragoneura sylvatica Curtis, 1837. This species is widely distributed in Europe. In Fennoscandia it has been found in Norway (Økland 1996, Økland \& Zaitsev 1997) and Sweden (Kurina et al. 2005). Reported from Finland with no locality data (Chandler 2005). Material: $1 \hat{\delta}$, Kb: Kotavaara, 29.VI.-2.VII.1998; 1 ô, Ok: Teerisuo, 12.IX.-2.X.1997.

\subsubsection{Subfamily Mycetophilinae}

\section{Tribe Exechiini}

Allodia (Brachycampta) angulata Lundström, 1913. A rare European species. Since the original description from Swedish Lapland (Lundströrm 1913), it has been reported from Great Britain (Chandler 1977), Denmark (Chandler \& Petersen 2001), Germany (Plassmann \& Schacht 1999, 2002), France (Chandler 2005) and Vologda province in Russia (Zaitzev 2003). Material: 2 ỗ, Kb: Kotavaara, 30.VII.-20.VIII.1998.

Anatella ankeli Plassmann, 1977. This species is known from several European localities (Chandler 1994b, 2005, Zaitzev 2003). In Fennoscandia, the species has been reported from Norway (Kjærandsen 1993) and Russian Karelia (Polevoi 2000). The record from Finland (Chandler 2005) is given with no locality data. Material: 1 §ิ, Ok: Pitkävaara, 26.VIII.-8.IX.1997.

Brachypeza (Paracordyla) obscura Winnertz, 1863. This species is widely distributed in Palaearctic (Zaitzev 2003). In Fennoscandia, the species is known from Russian Karelia (Polevoi 2000). The Finnish record (Chandler 2005) is given with no locality data. Material: $1 \hat{\jmath}, K b$ : Kotavaara, 17.-23.VII.1998; 1 §̂, Ok: Puntari, 2.-15.VII.1997.

Brevicornu occidentale Zaitzev, 1988. Described from North America (Zaitzev 1988) and later found in Norway (Økland 1996) and Russian Karelia (Polevoi 2000). Material: 1 ๙ , $K b$ : Kotavaara, 23.-26.VII.1998.
Exechia similis Laštovka \& Matile, 1974. This species is closely related to E. spinuligera Lundström, which is widely distributed in Europe, and has possibly been overlooked in Fennoscandia. Reported from Russian Karelia (Polevoi 2000). Material: $7 \hat{\jmath} \widehat{\jmath}, K b$ : Kotavaara, 25.VIII.8.IX.1998.

Exechia subfrigida Laštovka \& Matile, 1974. This species is closely related to E. frigida Boheman, which is a widely distributed Transpalaearctic species. It has been described from Mongolia (Laštovka \& Matile 1974) and then been reported from different localities in Russia (Zaitzev 2003). It has also been found in Norway (Søli 1994) and Sweden (Hedmark 2000). Mate-

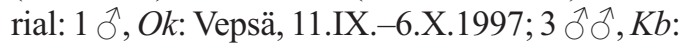
Kotavaara, 8.-29.IX.1997; 4 $\lesssim, K b$ : Kotavaara, 20.VIII.-8.IX.1998.

Exechiopsis (Exechiopsis) pseudindecisa Laštovka \& Matile, 1974. This species is apparently widely distributed in the Palaearctic region. In Fennoscandia, it was first recorded from Norway (Kjærandsen 1993, Økland \& Zaitzev 1997), and later on from Sweden (Plassmann 1980b), and from Karelia (Polevoi 2000). The record from Finland (Chandler 2005) lacks locality data. Material: $4 \hat{\jmath} \hat{\partial}$, St: Ahvenus, 25.VIII.-12.X. 1998; 1 ô, Ok: Vepsä, 13.-26.VIII.1997; 1 ô, Ta: Iso-Saarijärvi, 15.IX.-14.X.1998; 4 ふึฎ, Ok: Jonkeri, 27.VIII.-10.IX.1997; 8 ๙ิ ô, Kb: Kotavaara, 30.VII.-2.X.1998; 7 $\precsim$ ठै, Ok: Luhtavaara, 25.VIII.-9.IX.1997; 4 ठ̊̄, Ok: Näveri, 25.VIII.-2.X.1997; 1 đે, St: Nälkähittenkangas, 25.VIII.16.IX.1998; 2 ふ઼َ̂, Ok: Pellinkangas, 25.VIII.9.IX.1997; 2 ふึે, Ok: Puntari, 27.VIII.-10.IX. 1997; 3 ふึત̂, St: Rengassalo, 12.VIII.-13.X. 1998; 1 đ̃, Ta: Sudenpesänkangas, 17.-31.VIII. 1998; 2 ふึ ô, Ok: Jauhovaara, 11.-24.VIII.1997.

Rymosia pinnata Ostroverkhova, 1979. Described from Siberia and Russian Far East. The original figures of Ostroverkhova (1979; p. 175, figure 35:2), though being sketchy, allow reliable identification, especially due to the outstanding parameres resembling the wing of a bird. The male genitalia are illustrated in Fig. 1. The records following the original description have been from Sweden (Hedmark 2000) and from Finland with no locality data (Chandler 2005). Material: 1 ऽ, Ta: Kolmikoura, 24.VIII.15.IX.1998. 


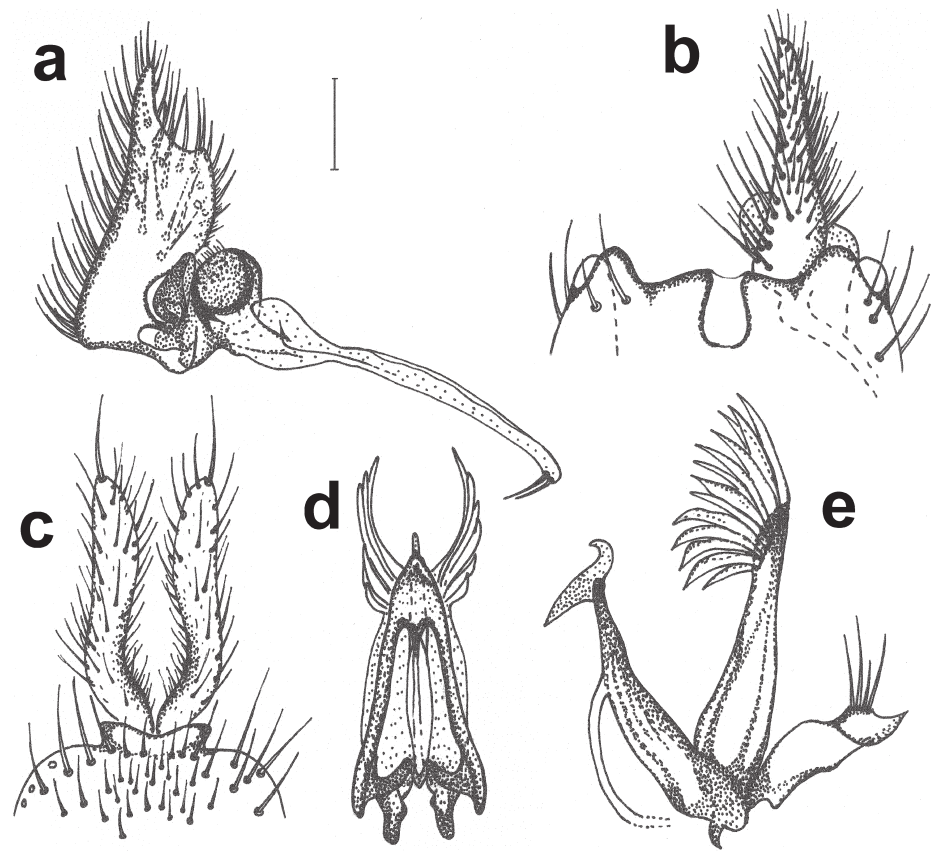

Fig. 1. Rymosia pinnata Ostroverkhova, male genitalia. - a. Left gonostylus, internal view. $-\mathrm{b}$. Gonocoxites and right gonostylus, ventral view. - c. Tergite IX and cerci, dorsal view. - d. Aedeagus and parameres, ventral view. $-\mathrm{e}$. Aedeagus and parameres, lateral view. Scale bar $0.1 \mathrm{~mm}$.
Tribe Mycetophilini

* Mycetophila morata Zaitzev, 1999. A species of the vittipes group. It was so far known only by the type material from Eastern Palaearctic - Sakhalin and Altai (Zaitzev 1999). Material: 1 o, $K b$ : Pirhu, 6.VI.1994; 1 §, Ok: Honkavaara, 11.IX.5.X.1997.

* Mycetophila ostentanea Zaitzev, 1998. Known by the type material from North-Western Russia, Vologda province (Zaitzev 1998, 2003) and by a record from Czech Republic (Chandler 2005). Material: $2 \widehat{\jmath}, K b$ : Kotavaara, 17.VII.11.VIII.1998.

Mycetophila pecinai Laštovka, 1963. Besides the type material from Bohemia, this species was reported from Sweden (Plassmann 1980b) and other European countries (Chandler 2005). The Finnish record given by the latter author contains no locality data. Material: $1 \hat{\jmath}, K b$ : Kotavaara, 8.-17.IX.1998; 1 ふૈ, Ok: Särkijärvi, 18.29.VII.1997.

Trichonta apicalis Strobl, 1898. A European species; in Fennoscandia, previously known only from Sweden (Plassmann 1980b). Material: 10 , $K b$ : Kotavaara, 25.VIII.-2.IX.1998.

Trichonta eximia Gagné, 1981. This species is common in North America. In Eurasia it was known from the Himalayas (Gagné 1981) and
Russian Karelia (Polevoi 2000). Material: 11

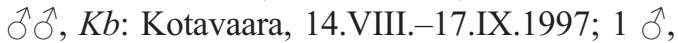
Ta: Musturi, 11.-24.VIII.1998.

* Trichonta nigritula Edwards, 1925. The species has been reinstated by P. Chandler (1992) after having been synonymized with Trichonta vitta (Meigen) by R. Gagné (1981). It has previously not been known from outside the British Isles. Material: $3 \hat{\jmath} \hat{\jmath}, K b$ : Kotavaara, 29.VI.08.IX.1998.

* Trichonta subterminalis Zaitzev \& Menzel, 1996. This species was described from Russian Far East (Zaitzev \& Menzel 1996). It is closely related to $T$. terminalis (Walker) and $T$. facilis Gagné and may have been overlooked in Europe. It must be noted that $T$. funebris Winnertz, which was considered a synonym of $T$. terminalis Walker by Edwards (1913), resembles $T$. subterminalis, by having large triangular ventral cleft on the gonocoxites (Dziedzicki 1915; table XI, figure 149). However, the figure of $T$. terminalis by R. Gagné (1981; p. 48, figure 93) in the revision of the genus, is distinctly different. Material: 1 ô, Kb: Kotavaara, 20.-25.VIII.1998.

\subsubsection{Subfamily Mycomyinae}

Mycomya fuscata Winnertz, 1863. Known from 

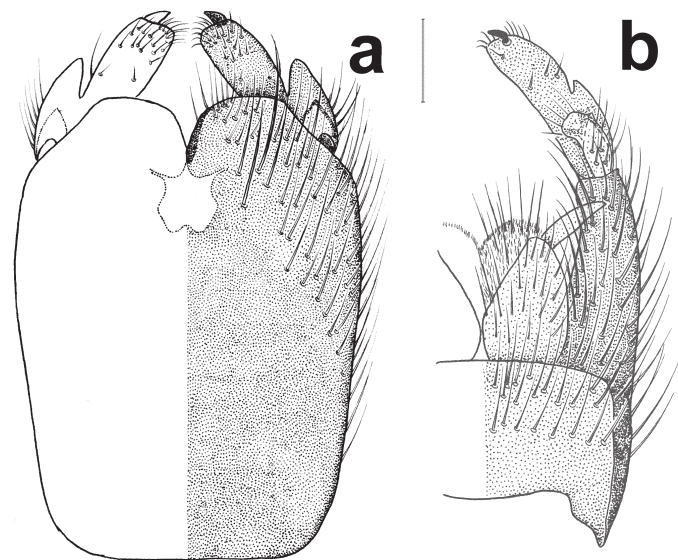

Fig. 2. Neuratelia sintenisi Lackschewitz, male genitalia. - a. Ventral view. - b. Dorsal view. Scale bar 0.1 $\mathrm{mm}$.

Europe and North America. In Fennoscandia, previously reported from Northern Sweden and Murmansk province (Väisänen 1984). Material: 2 §ิ ô, $O k$ : Teerisuo, 12.IX.-2.X.1997.

Mycomya norna Väisänen, 1984. Previously known by the holotype from Northern Sweden (Väisänen 1984), and additional records exist from South-Eastern Norway (Økland 1996), Germany and Finland (Chandler 2005). The Finnish record (Chandler 2005) has no locality data. On the basis of the present material this species appears to be common in old-growth forests in Southern Finland. All individuals were collected with bait traps. Material: $1 \hat{\jmath}, S t$ : Ahvenus, 25.VIII.-16.IX.1998; 17 ふ઼઼, Ta: Vesijako, 7.VII.-12.X.1998; 13 ふ઼, Ta: Iso-Saarijärvi, 15.VII.-13.X.1998; 4 गे, Ta: Kolmikoura, 31.VII.-24.VIII.1998; 13 ô, Ta: Kotiset, 7.VII.-12.X.1998; 11 ô, Ta: Lakeisnevankangas, 10.21.VIII.1998; 1 đ̃, Ok: Lauvuskylä, 13.26.VIII.1997; 88 ふふ઼, St: Lymylampi, 12.VI.13.X.1998; 48 §ิ, Ta: Metsäopisto, 24.VIII.17.IX.1998; 2 ऊิगे, St: Multinharju, 10.VIII.16.IX.1998; 20 ふิ઼, Ta: Musturi, 24.VI.15.X.1998; 102 ふึगे, St: Nälkähittenkangas, 12.VIII.-16.IX.1998; 1 ふ઼, Ok: Pellinkangas,

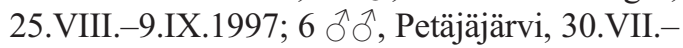

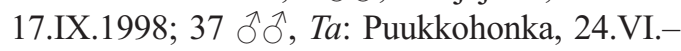
12.X.1998; 3 ऊิग, St: Rengassalo, 15.VII.13.X.1998; 1 गे, Ok: Riihisuo, 12.-25.VIII.1997;

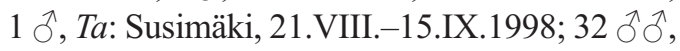
Ta: Sudenpesänkangas, 7.VII.-21.IX.1998; 1 गे, Ok: Elimyssalo, 28.VII.-7.VIII.1997.
* Neoempheria winnertzi Edwards, 1913. Known from Europe and Iran. No previous records from Fennoscandia, with the exception of one from Finland with no locality data (Chandler 2005). Material: 1 đ, Ok: Teerisuo, 16.-29.VII. 1997; 3 ふ઼ે, Ok: Urpovaara, 16.VII.-11.VIII. 1997.

\subsubsection{Subfamily Sciophilinae}

* Neuratelia sintenisi Lackschewitz, 1937. Previously known only by type material from Estonia (Lackschewitz 1937) and by an additional record from Czech Republic (Ševčík 2001). Reported from North-Western Russia and Finland with no locality data (Chandler 2005). Male genitalia are illustrated in Fig. 2. Material: $2 \partial^{\lambda}, K b$ : Kotavaara, 23.VII.-6.VIII.1998; 1 ふ̂, St: Nälkähittenkangas, 15.-31.VII.1998.

Phthinia setosa Zaitzev, 1994. A rare species known so far only from Fennoscandia: Russian Karelia (Zaitzev, 1994), Norway (Økland 1996)

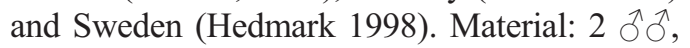
Kb: Kotavaara, 23.VII.-11.VIII.1998.

Sciophila modesta Zaitzev, 1982. A Holarctic species; widely distributed in North America. In the Palaearctic region mostly recorded from northern areas including Russian Karelia (Zaitzev 1994). Material: 3 $\widehat{\jmath}, K b$ : Kotavaara, 22.VI.-6.VIII.1998.

Sciophila nonnisilva Hutson, 1979. A Holarctic species. Widely distributed in Europe (Chandler 2005), recorded also from Azerbaidjan (Zaitzev 1994). In Fennoscandia, the species has previously been found in Norway (Økland \& Zaitzev 1997) and Sweden (Kurina et al. 2005). Material: 1 đ̊, Kb: Kotavaara, 13.-17.VII.1998.

Sciophila persubtilis Polevoi, 2001. This species has previously been known only by the type material from Russian Karelia (Polevoi 2001). Material: $6 \hat{\jmath} \widehat{\jmath}, \mathrm{Kb}$ : Kotavaara, 11.VI.-8.IX. 1998.

Acknowledgements. We are grateful to Timo Hokkanen (North Karelian Environment Centre, Joensuu), Raimo Heikkilä and Gergely Varkonyi (Kainuu Regional Environment Centre, Research Centre of the Friendship Park, Kuhmo) for providing us with long-term trapping material. We also thank Juha Siitonen (Finnish Forest Research Institute, Vantaa) and the referees for valuable comments on the manuscript. This paper is part of the project "Finnish 
fungus gnats (Diptera, Mycetophilidae, etc.): faunistics, habitat requirements and threat status". The financial support from the Finnish Ministry of Environment is acknowledged.

\section{References}

Chandler, P. J. 1992: A review of the British Phronia Winnertz and Trichonta Winnertz (Diptera, Mycetophilidae). - Entomologist's Monthly Magazine 128: 237-254.

Chandler, P. J. 1994a: The fungus gnats of Israel (Diptera: Sciaroidea, excluding Sciaridae). - Israel Journal of Entomology 28: 1-100.

Chandler, P. J. 1994b: Four species of Anatella Winnertz (Diptera, Mycetophilidae) new to the British Isles. Dipterist's Digest, Second series 1: 9-12.

Chandler, P. J. 1977: Some fungus-gnats of the tribe Exechiini (Dipt., Mycetophilidae) new to the British Isles. - Proceedings of the British Entomological and Natural History Society 10: 71-85.

Chandler, P. J. 2002: Heterotricha Loew and allied genera (Diptera: Sciaroidea): offshots of the stem group of Mycetophilidae and/or Sciaridae? - Annales de la Société Entomologique de France (N. S.) 38: 101144.

Chandler, P. J. 2005: Fauna Europaea: Mycetophilidae. In: de Jong, H. (ed.), Fauna Europaea: Diptera, Nematocera. Fauna Europaea version 1.2. Available at http://www.faunaeur.org (Accessed October 2005).

Chandler, P. J. \& Petersen, F. T. 2001: Mycetophilidae. In: Petersen, F. T. \& Meier, R. (eds.), A preliminary list of the Diptera of Denmark: 151-156. Copenhagen.

De Jong, H. (ed.) 2005: Fauna Europaea: Superfamily Sciaroidea. Fauna Europaea version 1.2. - Available at http://www.faunaeur.org (Accessed October 2005).

Dziedzicki, H. 1915: Atlas organów rozrodczych (hypopygium) typów Winnertz'a i gatunków znajdujących się w jego zbiorze Mycetophilidów. - Wydawnictwa Towarzystwa Naukowego Warszawskiego Ser. III. P. 1-16. [In Polish.]

Edwards, F. W. 1913: Notes on British Mycetophilidae. Transactions of the Entomological Society of London 1913: 335-382.

Edwards, F. W. 1925: British Fungus-Gnats (Diptera, Mycetophilidae) with a revised generic classification of the family. - Transactions of the Entomological Society of London 1924: 505-670.

Frey, R. \& Storå, R. 1941: Diptera. Nematocera. Enumeratio Insectorum Fenniae VI: 43-56.

Gagné, R. J. 1981: A monograph of Trichonta with a model for the distribution of Holarctic Mycetophilidae (Diptera). - Technical Bulletin USDA 1638: 1-64.

Hackman, W. 1970: New species of the genus Phronia Winnertz (Diptera, Mycetophilidae) from Eastern Fennoscandia and notes on synonymies in this genus. - Notulae Entomologicae 50(2): 41-60.

Hackman, W. 1971: Three new species of the Allodia lu- gens group from Northern Europe. - Annales Entomologici Fennici 37: 3-7.

Hackman, W. 1980: A check list of the Finnish Diptera I. Nematocera and Brachycera (s.str.). - Notulae Entomologicae 60: 17-48.

Hedmark, K. 1998: Svampmyggor - nya arter för Sverige och Finland (Diptera: Mycetophilidae s. lat.). Entomologisk Tidskrift 119: 1-12.

Hedmark, K. 2000: Svampmyggor i taigan - nya arter för Sverige i ett fennoskandiskt perspektiv (Diptera: Sciaroidea excl. Sciaridae). — Entomologisk Tidskrift 121: 73-89.

Hippa, H. \& Vilkamaa, P. 2005: The genus Sciarotricha gen. n. (Sciaridae) and the phylogeny of recent and fossil Sciaroidea (Diptera). - Insect Systematics \& Evolution 36: 121-144.

Jakovlev, J. 1995: Species diversity and abundance of fungivorous Diptera in forests and city parks of Russian Karelia. - International Journal of Dipterological Research 6: 335-362.

Kallweit, U. \& Jashhof, M. 2004: Sciarosoma borealis Chandler, 2002: a remarkable addition to the German fauna of Sciaroidea (Diptera: Bibionomorpha). Studia Dipterologica 11: 127-128.

Kjærandsen, J. 1993: Diptera in mines and other cave systems in Southern Norway. - Entomologica Fennica 4: 151-160.

Krogerus, R. 1960: Ökologische Studien über Nordische Moorarthropoden. - Commentationes Biologicae 2: $1-238$.

Kurina, O., Polevoi, A., Götmark, F., Ökland, B., Frank, N. \& Hedmark, K. 2005: Fungus gnats (Diptera: Sciaroidea excl. Sciaridae) in the Swedish boreonemoral forests. - Studia Dipterologica 11: 471-488.

Lackschewitz, P. 1937: Die Fungivoriden des Ostbaltischen Gebietes. - Arbeiten des NaturforscerVereins zu Riga (Neue Folge) 21: 1-47.

Laštovka, P. \& Matile, L. 1974: Mycetophilidae de Mongolie. - Acta Zoologica Academiae Scientiarum Hungaricae 20: 93-135.

Laštovka, P. \& Matile, L. 1988: Tribe Gnoristini. — In: Soos, A. \& Papp, L. (eds.), Catalogue of Palaearctic Diptera. Vol. 3. Ceratopogonidae - Mycetophilidae: 242-253. Akadémiai Kiadó, Budapest.

Lundström, C. 1906: Beiträge zur Kenntnis der Dipteren Finlands. I. Mycetophilidae. — Acta Societas pro Fauna et Flora Fennica 29: 1-50.

Lundström, C. 1909: Beiträge zur Kenntnis der Dipteren Finlands. IV. Supplement: Mycetophilidae. - Acta Societas pro Fauna et Flora Fennica 32: 1-63.

Lundström, C. 1912: Beiträge zur Kenntnis der Dipteren Finlands. VIII. Supplement 2. Mycetophilidae, Tipulidae, Cylindrotomidae and Limnobiidae. Acta Societas pro Fauna et Flora Fennica 36: 1-70.

Lundström, C. 1913: Neue oder wenig bekannte europäische Mycetophiliden. - Annales Musei Nationalis Hungarici 11: 305-322.

Lundström, C. 1914: Beiträge zur Kenntnis der Dipteren Finlands. IX. Supplement 3. Mycetophilidae. - Acta Societas pro Fauna et Flora Fennica 39: 1-26. 
Matile, L. 1990: Recherches sur la systématique et l'évolution des Keroplatidae (Diptera, Mycetophiloidea). - Mémoires du Muséum national d'Histoire naturelle Ser. A.148: 1-682.

Ostroverkhova, G. P. 1979: (Fungus gnats (Diptera, Mycetophiloidea) of Siberia) — Tomsk University, Tomsk: 308 pp. [In Russian.]

Økland, B. 1996: Unlogged forests: important sites for preserving the diversity of Mycetophilids (Diptera, Sciaroidea). - Biological Conservation 76: 297-310.

Økland, B. \& Zaitzev, A. I. 1997: Mycetophilids (Diptera, Sciaroidea) from southeastern Norway. - Fauna Norvegica Ser. B 44: 27-37.

Plassmann, E. 1974: Dritter Narchtrag zu der Mycetophiliden-Sammlung des Senckenberg-Museums Frankfurt am Main. - Senckenbergiana Biologica 55: 351-352.

Plassmann, E. 1978: Pilzmücken aus Messaure in Sweden. I. Barberfallenfänge (Diptera, Mycetophilidae). Senckenbergiana Biologica 58: 147-156.

Plassmann, E. 1979: Pilzmücken aus Messaure in Sweden. II. Luftstrom-Fallenfänge (Insecta: Diptera, Mycetophilidae). - Senckenbergiana Biologica 59: 371388.

Plassmann, E. 1980a: Drei neue Pilzmücken aus Tirol und Bayern. - Spixiana 3: 209-214.

Plassmann, E. 1980b: Pilzmücken aus Messaure in Sweden. III. Lichtfallenfänge (Insecta: Diptera, Mycetophilidae). - Senckenbergiana Biologica 60: 175-189.

Plassmann, E. \& Schacht, W. 1999: Fundort Schöngeising. Zweite Ergänzungliste zu den Pilzmücken mit Beschreibung von fünf neuen Arten (Diptera Sciaroidea: Macroceridae, Mycetophilidae). — Entomofauna 20: 281-288.

Plassmann, E. \& Schacht, W. 2002: Zweiflüger aus Bayern XXII (Diptera Sciaroidea: Ditomyiidae, Bolitophilidae, Diadocidiidae, Keroplatidae, Mycetophilidae). — Entomofauna 23: 237-248.

Polevoi, A. V. 1995: New and poorly-known species of the families Bolitophilidae, Diadocidiidae and Keroplatidae from Eastern Fennoscandia (Diptera, Nematocera). - Zoosystematica Rossica 4: 177-182.

Polevoi, A.V. 2000: Fungus gnats (Diptera: Bolitophilidae, Ditomyiidae, Keroplatidae, Diadocidiidae, Mycetophilidae) in Karelia. — Karelian Research Centre, Russian Academy of Sciences, Petrozavodsk. 84 pp. [In Russian.]

Polevoi, A.V. 2001: New and little known species of the fungus gnat subfamilies Mycomyinae and Sciophilinae (Diptera, Mycetophilidae) from Eastern Fennoscandia. - Entomologicheskoe Obozrenie 80: 518-526. [In Russian.]

Polevoi, A. V. \& Hedmark, K. 2004: New species of the genus Boletina Winnertz (Diptera: Mycetophilidae) from Fennoscandia. - Entomologica Fennica 15:2333.

Polevoi, A. \& Jakovlev, J. 2004: Changes in the Finnish fauna of fungus gnats (Diptera: Mycetophilidae s. 1.) since Hackman's checklist. - Sahlbergia 9:135-140.

Silfverberg, H. 1981: Additions to the Finnish insect fauna during the years 1976-1980. — Notulae Entomologicae 61: 45-61.

Silfverberg, H. 1986: Additions to the Finnish insect fauna during the years 1981-1985. - Notulae Entomologicae 66: 131-152.

Silfverberg, H. 1991: Changes 1986-1990 in the list of Finnish insects. - Entomologica Fennica 2: 9-17.

Silfverberg, H. 1996: Changes 1991-1995 in the list of Finnish insects. - Entomologica Fennica 7: 39-49.

Silfverberg, H. 2001: Changes 1996-2000 in the list of Finnish insects. - Entomologica Fennica 12: 227243.

Søli, G. E. E. 1994: Fungus gnats from Jostedalen, West Norway (Diptera; Diadocidiidae and Mycetophilidae). - Fauna Norvegica Ser. B 41: 1-12.

Ševč́k, J. 2001: New records of Diadocidiidae, Keroplatidae and Mycetophilidae (Diptera: Sciaroidea) from the Czech Republic. — Casopis Slezského Muzea Opava (A) 50: 159-169.

Tuomikoski, R. 1966: Generic taxonomy of the Exechiini (Dipt., Mycetophilidae). - Annales Entomologici Fennici 32: 159-194.

Väisänen, R. 1984: A monograph of the genus Mycomya Rondani in the Holarctic region (Diptera, Mycetophilidae). - Acta Zoologica Fennica 177: 1-346.

Zaitzev, A. I. 1988: Fungus gnats of the Sericoma, Griseicolle and Ruficorne species groups of the genus Brevicornu Marshall (Diptera, Mycetophilidae) of Holarctic fauna. - Entomologicheskoe Obozrenie 67: 391-404. [In Russian.]

Zaitzev, A. I. 1991: Mycetophiloid dipterans of the genus Keroplatus Bosc (Diptera, Keroplatidae) of the USSR Fauna. - Byulleten Moscowskogo Obshestva Ispytateley Prirody, Otdelenie Biologiya 96: 39-47. [In Russian.]

Zaitzev, A. I. 1994: Fungus gnats of the fauna of Russia and adjacent regions. Part 1. — Nauka, Moscow. 288 pp. [In Russian.]

Zaitzev, A. I. 1998: Six new species of fungus gnats of the genus Mycetophila Meigen from Russia (Diptera, Mycetophilidae). - Studia dipterologica 5:211-216.

Zaitzev, A. I. 1999: Fam. Mycetophilidae - Fungus gnats. - Key to the insects of Russian Far East. Vol. VI. Diptera and Syphonaptera. Pt. 1. Vladivostok, Dal'nauka, 6: 151-239. [In Russian.]

Zaitzev, A. I. 2003: Fungus gnats (Diptera, Scaroidea) of the fauna of Russia and adjacent regions. Part II. - International Journal of Dipterological Research 14: 77386.

Zaitzev, A. I. \& Menzel, F. 1996: New data on the fungus gnats from the Russian Far East (Diptera: Sciaroidea). — Beiträge zur Entomologie 46: 159-167.

Zaitzev, A. I. \& Økland, B. 1994: Four new species of fungus gnats from Norway (Diptera, Mycetophilidae). Studia Dipterologica 1: 181-186. 